\title{
Methaemoglobinemia Developing Following Lidocain Use
}

\begin{abstract}
Introduction
Methaemoglobin results from oxidation of haemoglobin ( $\mathrm{Hgb})$ that needs to be in the ferrous $\left(\mathrm{Fe}^{+2}\right)$ form in order to transport oxygen to the ferric $\left(\mathrm{Fe}^{+3}\right)$ form. The methaemoglobin reductase system permits iron to be stored in a reduced state in the erythrocyte. It may occur in association with congenital or acquired causes. Congenitally, it occurs in the presence of deficiencies of glucose- 6 - $p$ dehydrogenase, cytochrome b5 and nicotinamide adenine dinucleotide (NADH) diaphorase, which permit methaemoglobin reduction in the organism, and in the presence of abnormal Hgb. Of the total Hgb, methaemoglobin represents $1 \%$ and does not exceed 2-3\% under physiological conditions. It appears when the balance between oxidation and reduction is compromised in the presence of increased oxidants, decreased reduction capacity or abnormal Hgb. Exposure to chemical agents or drugs (amyl nitrate, nitroglycerine, dapsone, phenacetin, phenytoin, primaquine, sulfonamides and local anaesthetics) is the most common cause of acquired methaemoglobinemia (1,2).
\end{abstract}

High amounts of nitric oxide are released in patients with sepsis. The nitric oxide that forms is converted into methaemoglobin or nitrate. Septic patients have reported higher levels of methaemoglobin compared to nonseptic patients (3).

We reported a 1-year-old girl, administered local lidocaine for analgesic purposes due to burns who later developed methaemoglobinemia and was treated in our paediatric intensive care unit (PICU).
öZ

Methemoglobinemi, iki değerli hemoglobin demirinin okside olup üç değerli duruma geçmesiyle oluşan ve dokulara yeterli oksijen taşınamaması nedeniyle siyanoz ile karakterize olan ciddi bir hematolojik hastalıktır. Burada, yanık nedeniyle analjezik amaçlı lokal lidokain uygulanan, methemoglobinemi gelișen ve çocuk yoğun bakım ünitemizde tedavi edilen 1 yaşında Suriye'li kız hasta sunulmuştur.

Anahtar Kelimeler: Methemoglobinemi, lidokain, metilen mavisi, siyanoz

\section{Case Report}

A 1-year-old refugee girl who suffered feet burns from hot water and developed cyanosis following application of lidocaine-containing ointment was transferred to our PICU. We learnt she had no previous symptoms, and that peripheral cyanosis had developed 2 hours after ointment application, 12 hours after hot water poured on her feet. Family consent was obtained and she was admitted to the PICU. At physical examination, blood pressure was $90 / 50 \mathrm{mmHg}$, heart rate was $160 \mathrm{bpm}$ and respiration rate $43 /$ minute. The patient was agitated, and perioral and peripheral cyanosis were present. The burn area covered $10 \%$ of the lower extremities. Oxygen saturation measured using a pulse oximeter was $65 \%$. Arterial blood gas examination was performed while $80 \%$ oxygen was administered using a high flow nasal cannula, pH was measured at 7.39, $\mathrm{pO}_{2}$ at $110 \mathrm{mmHg}, \mathrm{pCO}_{2}$ at $41 \mathrm{mmHg}, \mathrm{HCO}_{3}$ at 24.3 $\mathrm{mEq} / \mathrm{l}, \mathrm{SaO}_{2}$ at $98 \%$ and methaemoglobin levels at $12 \%$. At complete blood count, Hgb was $12 \mathrm{~g} / \mathrm{dL}$, white blood cell: 7,400 $\mathrm{mm}^{3}$ and platelet: $319,000 / \mathrm{mm}^{3}$. Posterior-anterior chest radiography was normal, and no pathology was determined at echocardiography. Glucose-6-phosphat dehydrogenase levels were within normal limits. Methaemoglobinemia was suspected, and ascorbic acid therapy at $300 \mathrm{mg} / \mathrm{kg}$ was administered intravenous (IV). Methylene blue obtained from another institution was subsequently administered IV at a dose of $1.5 \mathrm{mg} / \mathrm{kg}$. Cyanosis decreased on the $3^{\text {rd }}$ hour of treatment and subsequently resolved entirely. Methaemoglobin levels decreased consecutively to 5.8\% and 2.9\% (Table 1). Oxygen saturation measured using a pulse oximeter increased, and 
oxygen therapy was discontinued. The patient's general condition was good and clinical findings had improved, and the patient was transferred to the paediatric department.

\section{Discussion}

The presence of abnormal Hgb must be investigated once congenital heart diseases and respiratory diseases have been excluded in patients with cyanosis and desaturation. Cyanosis despite normal $\mathrm{PaO}_{2}$ levels in arterial blood gas, and cyanosis failing to resolve despite oxygen therapy is an important finding in cases of methaemoglobinemia (4). In our case too, although $\mathrm{PaO}_{2}$ was $120 \mathrm{mmHg}, \mathrm{SaO}_{2} 98 \%$ and $\mathrm{SpO}_{2} 65 \%$, no clinical response to oxygen therapy was achieved.

Under normal conditions, blood methaemoglobin levels are 1-2\%. Since methaemoglobin reductase activity and fetal $\mathrm{Hgb}$ are more easily oxidised in the first 3 months of life, there is a higher risk of development of methaemoglobinemia in association with toxic substances (5).

Cyanosis frequently develops when methaemoglobin levels are $10-20 \%$. Respiratory difficulty, dizziness, headache, tachycardia, lethargy, nausea and vomiting due to tissue hypoxia may be observed at levels of 30\% or above, and lethargy, stupor and syncope at levels above 55\%. Higher levels may lead to cardiac arrhythmias and circulatory insufficiency. Level above $70 \%$ are fatal unless treated (6). Although our patient's methaemoglobin level was $12 \%$, agitation, tachypnea, and perioral and peripheral cyanosis were present. Higher methaemoglobin levels are reported as necessary for tachypnea and tachycardia in the literature. We thought that these findings might have been due to agitation.

Blood turns chocolate-brown in colour in case of high methaemoglobin concentrations. Our patient's blood had a characteristic chocolatebrown colour too. Treatment must be initiated when methaemoglobin levels exceed $20 \%$ and the patient is symptomatic, or if levels exceed $30 \%$ and the patient is asymptomatic. Treatment may also be initiated at lower level in cases of anaemia and cardiopulmonary problems. Methylene blue is administered IV at a dose of $2 \mathrm{mg} / \mathrm{kg}$ in infants, $1.5 \mathrm{mg} / \mathrm{kg}$ in children and $1 \mathrm{mg} / \mathrm{kg}$ in adults. Methaemoglobin levels generally decrease to below $10 \%$ within $30 \mathrm{~min}$. The dose may be repeated hourly. Paradoxically, however, a dose greater than $7 \mathrm{mg} /$ $\mathrm{kg}^{-1}$ is not recommended since this can trigger methaemoglobinemia. Methylene blue must not be used in Glucose-6-phosphate dehydrogenase (G6PD) deficiency (7). Our patient's G6PD levels were normal. Methylene blue was administered IV at a dose of $1.5 \mathrm{mg} /$ $\mathrm{kg}^{-1}$ due to agitation, tachycardia, tachypnea and cyanosis despite methaemoglobin levels of 12\%. Sulfhemoglobinemia, G6PD deficiency, congenital NADPH Met- $\mathrm{Hb}$ reductase deficiency and, rarely, toxins must

\begin{tabular}{|c|c|c|c|}
\hline & 0 hour & 3 hour & 12 hour \\
\hline Methaemoglobin level (\%) & 12 & 5.8 & 2.9 \\
\hline Oxygen saturation (\%) & 65 & 90 & 97 \\
\hline Heart rate (bpm) & 160 & 142 & 121 \\
\hline
\end{tabular}

be considered at differential diagnosis in cases that do not respond to methylene blue therapy (8). Ascorbic acid therapy is more used longterm and in oral form in congenital methaemoglobinemias. Hyperbaric oxygen therapy and exchange transfusion may be required in patients with methaemoglobin levels exceeding 70\% (9). Experimental studies have also investigated the use of $\mathrm{N}$-acetylcysteine, cimetidine and ketoconazole in methaemoglobinemia (10).

\section{Conclusion}

Methaemoglobinmia should be considered at differential diagnosis in cases developing cyanosis after local anaesthetic use, and care must be taken to ensure that methylene blue suitable for IV use is available in centres where these agents are frequently employed.

\section{Ethics}

Informed Consent: Family consent was obtained and she was admitted to the PICU.

Peer-review: Externally and internally peer-reviewed.

Authorship Contributions: Surgical and Medical Practices - S.E., T.B.M; Concept- G.A.; Design - S.E.; Data Collection or Processing - T.B.; Analysis or Interpretation - S.E, H.I.; Literature Search - G.A.; Writing - S.E.

Conflict of Interest: No conflict of interest was declared by the authors.

Financial Disclosure: The authors declared that this study received no financial support.

\section{References}

1. David SR, Sawal NS, Bin Hamzah MN, Rajabalaya R. The blood blues: A review on methemoglobinemia, J Pharmacol Pharmacother 2018; 9: 1-5.

2. Rehman HU. Methemoglobinemia. West J Med 2001; 175: 193-6.

3. Çağlar A, Er A, Karaarslan U, Ulusoy E, Akgül F, İnci G, et al. Severe methemoglobinemia due to nitrite intoxication in a child was misdiagnosed with sepsis. J Pediatr Emerg Intensive Care Med 2016; 3: 155-8.

4. Cheifetz IM, Venkataraman ST, Hamel DS. Respiratory monitoring. Nichols DG, editor. Roger's Textbook of Pediatric Intensive Care. 4th ed. Philadelphia: Lippincott Williams and Wilkins; 2008.p.666-9.

5. Dağdaş S, Ceran F. Methemoglobinemia and Other Dyshemoglobinemias Türkiye Klinikleri J Hematol-Special Topics 2016; 9: 62-9.

6. Erol MÇ, Alaçatı N, Dursun O. Methemoglobinemia Associated with Prilocaine Use in Circumcision. J Pediatr Emerg Intensive Care Med 2016; 3: 36-8.

7. do Nascimento TS, Pereira RO, de Mello HL, Costa J. Methemoglobinemia: From diagnosis to treatment. Rev Bras Anestesiol 2008; 58: 651-64.

8. Patnaik S, Natarajan MM, James EJ, Ebenezer K. Methylene blue unresponsive methemoglobinemia. Indian J Crit Care Med 2014; 18: 253-5.

9. Altıntop I, Sanrı E, Tatlı M, Akçin M, Denizbașı A. Methemoglobinemia treated with hyperbaric oxygen therapy: A case report. Turk J Emerg Med 2018 ; 18: 176-8.

10. Aydoğan M, Toprak DG, Türker G, Zengin E, Arısoy ES, Gökalp S. Prilokaine bağlı toksik methemoglobinemide intravenöz askorbik asit kullanımı:iki vaka takdimi. Çocuk Sağlığı ve Hastalıkları Dergisi 2005; 48: 65-8. 